\title{
ICT as a Source of Output and Productivity Growth in Finland
}

\author{
Jukka Jalava \\ Statistics Finland and Helsinki School of Economics \\ and \\ Matti Pohjola \\ Helsinki School of Economics and HECER
}

Discussion Paper No. 52

February 2005

ISSN 1795-0562

HECER - Helsinki Center of Economic Research, P.O. Box 17 (Arkadiankatu 7), FI-00014 University of Helsinki, FINLAND, Tel +358-9-191-28780, Fax +358-9-191-28781, E-mail info-hecer@helsinki.fi, Internet www.hecer.fi 


\title{
ICT as a Source of Output and Productivity Growth in Finland*
}

\begin{abstract}
The paper analyzes the impacts of information and communications technology (ICT) on output and labour productivity growth in Finland in 1995-2002. Nearly one-third of GDP growth at the rate of 4.09 per cent stemmed from ICT-both as a component of output and as a factor of total input. ICT also accounted for 1.08 percentage points of the observed labour productivity growth at the average rate of 2.51 per cent. The contribution of ICT capital deepening was 0.60 percentage points. The rest is attributed to multi-factor productivity growth in ICT production.
\end{abstract}

JEL Classification: O3, O4, O5

Keywords: ICT, information and communications technology, economic growth, labour productivity, multi-factor productivity

Jukka Jalava

Economic Statistics

$6 \mathrm{C}$

FIN-00022 Statistics Finland

FINLAND

e-mail: jukka.jalava@stat.fi
Matti Pohjola

Helsinki School of Economics

P.O. Box 1210

FIN-00101 Helsinki

FINLAND

e-mail: matti.pohjola@hse.fi

\footnotetext{
* The opinions expressed here are those of the authors and do not necessarily reflect the views of Statistics Finland. Jukka Jalava's research is partly supported by the EU KLEMS project "Productivity in the European Union: A Comparative Industry Approach", funded by the European Commission, Research Directorate General as part of the 6th Framework Programme, Priority 8, "Policy Support and Anticipating Scientific and Technological Needs". Matti Pohjola gratefully acknowledges financial support from the Yrjö Jahnsson Foundation.
} 


\section{Introduction}

Finland transformed itself in the $20^{\text {th }}$ century from a backward agrarian country reliant on its natural resources into a modern industrial society whose telecommunications manufacturing is at the cutting edge of the world. Back in 1950 the Finnish living standard, as measured by GDP per capita, was less than half of the US equivalent. In 2003, this ratio was three-quarters. ${ }^{1}$ The road to prosperity, however, has not always been smooth. The largest peace-time hurdle was the recession in the early 1990 s when real GDP plummeted by 11 per cent during the years from 1990 to 1993.

The tale of Finnish economic growth is very much one of productivity. From the year 1900 to 2003, the standard of living has increased 12-fold although the number of hours worked per capita has declined. This was possible because labour productivity - GDP per hour worked—rose 14-fold.

In a historical perspective, Finland is now in a similar situation as it was a century ago when the basis for electricity - the new technology of the day-was laid. The past economic success was achieved through the adoption of electricity in the extraction of rents from its natural endowments - forests and minerals. The process created the present industrial structure in which the forest and metal sectors dominate. At best, GDP per hour worked increased at the average rate of five per cent per year. Starting in the early 1970s, however, there has been a worrisome shift into slower gear, as the gains from industrialization have been depleting. After the turn of the millennium, labour productivity change averaged only half of its earlier peak figures (Jalava \& Pohjola, 2004).

The slowing down of productivity growth would not be a policy problem if nothing could be done about it. But as the recent success of the US economy shows, decelerating productivity growth can be turned into an accelerating one. The observed step-up in the trend of US labour productivity in the post-1995 era was traced by Jorgenson, Ho and Stiroh (2003) to the impact of information and communications technology (ICT) on GDP growth. This growth resurgence prompts the question: How can the same outcome be accomplished elsewhere?

Like electricity, ICT is a general purpose technology that spreads to all sectors of the economy, improving and becoming cheaper over time and facilitating the creation of new goods, services and modes of operation. It affects economic growth both as a component of aggregate output in the form of ICT production and as a component of aggregate input in the form of ICT capital services. Furthermore, it has an impact on growth via the effect of multi-factor productivity (MFP) gains induced by rapid technological advances in the ICT producing industries.

We apply neoclassical growth accounting to delineate ICT's influence on output and labour productivity growth in Finland. Due to the extraordinary severity of the recession in the early 1990s, we focus on the 1995-2002 period. In Section 2 we

\footnotetext{
${ }^{1}$ Source: Groningen Growth and Development Centre and The Conference Board, Total Economy Database, August 2004, http://www.ggdc.net
} 
outline the growth accounting methodology. Section 3 describes the data, and Section 4 presents the results. The last section concludes and presents a projection of labour productivity growth in the future.

\section{Growth accounting methodology}

Information and communications technology affects economic growth both as a component of aggregate output in the form of ICT production and as a component of aggregate input in the form of ICT capital services. Therefore, we express the aggregate production function in the form of the production possibility frontier as formulated by Jorgenson, Ho and Stiroh (2003):

$$
Y\left(Y_{I C T}(t), Y_{O}(t)\right)=A(t) F\left(K_{I C T}(t), K_{O}(t), L(t)\right)
$$

where, at any given time $t$, aggregate value added $Y$ is assumed to consist of the production of ICT goods and services $Y_{I C T}$ as well as of other production $Y_{O}{ }^{2}$. These outputs are produced from aggregate inputs consisting of ICT capital services $K_{I C T}$, other capital services $K_{O}$ and labour services $L$. The level of technology or multifactor productivity is represented in the Hicks neutral or output-augmenting form by parameter $A$.

Assuming constant returns to scale in production and competitive product and factor markets, growth accounting gives the share weighted growth of outputs as the sum of the share weighted inputs and growth in multi-factor productivity:

$$
\Delta \ln Y=\bar{w}_{I C T} \Delta \ln Y_{I C T}+\bar{w}_{O} \Delta \ln Y_{O}=\bar{v}_{I C T} \Delta \ln K_{I C T}+\bar{v}_{O} \Delta \ln K_{O}+\bar{v}_{L} \Delta \ln L+\Delta \ln A,
$$

where $\Delta$ refers to a first difference, i.e. $\Delta x \equiv x(t)-x(t-1)$, and where the time index $t$ has been suppressed for the economy of exposition. The weights $\bar{w}_{I C T}$ and $\bar{w}_{O}$ depict the average nominal output shares of ICT and other production, respectively, and they sum to one. The weights $\bar{v}_{I C T}, \bar{v}_{O}$ and $\bar{v}_{L}$ also sum to one and respectively represent the average nominal income shares of ICT capital, other capital and labour. All shares are averaged over the periods $t$ and $t-1$.

We use equation (2) to show that information and communications technology can have an impact on economic growth via three channels. First, the most obvious effect on the total value added generated in an economy is the direct contribution of the production of ICT goods and services. This contribution $-\bar{w}_{I C T} \Delta \ln Y_{I C T}$ in eq. (2) - is computed by multiplying ICT's nominal output share by the growth rate of the volume of its production.

Second, ICT capital services contribute to economic growth as an input into production. In the United States, the benefits from ICT use even surpass the gains from its production in the post-1995 era (Jorgenson, Ho and Stiroh 2003). The way

\footnotetext{
${ }^{2}$ Our approach is different from Jorgenson, Ho and Stiroh (2003) in that they include only ICT investment goods in the production of ICT.
} 
to estimate the growth contribution of ICT capital services is to weight its rate of change with a coefficient that represents its share in nominal income: $\bar{v}_{I C T} \Delta \ln K_{I C T}$.

The third channel for information and communications technology to enhance economic growth is via the impact of ICT production on multi-factor productivity:

$$
\Delta \ln A=\bar{w}_{I C T} \Delta \ln A_{I C T}+\bar{w}_{O} \Delta \ln A_{O}
$$

where $\Delta \ln A_{I C T}$ is MFP growth in ICT production and $\Delta \ln A_{O}$ is MFP growth in other production. The weights $\bar{w}_{I C T}$ and $\bar{w}_{O}$ applied in decomposing the aggregate MFP growth are the same as those used in the measurement of the direct output contributions.

To estimate sectoral multi-factor productivity growth, we employ the price dual method. It uses data on the prices of inputs and outputs, rather than their quantities, to calculate MFP growth. The underlying idea is that declines in the relative prices of ICT goods reflect productivity growth in their production $\Delta \ln A_{I C T}$. Assuming that the aggregate share weighted price change of labour and capital is representative also at the disaggregated level, MFP growth in ICT production can be calculated as the negative of the ICT output price change relative to the share weighted price change of labour and capital (Jorgenson, Ho and Stiroh 2003). Multiplying this by the output share $\bar{w}_{I C T}$ gives ICT's contribution to the aggregate MFP growth. The contribution of non-ICT productivity growth $\bar{w}_{O} \Delta \ln A_{O}$ is obtained from equation (3) as a residual.

To assess the contribution of ICT on the growth of labour productivity, we denote the number of hours worked by $H(t)$ and labour productivity by $Y(t) / H(t)$. The basic growth accounting equation (2) can be rewritten as

$$
\begin{aligned}
& \Delta \ln Y-\Delta \ln H= \\
& v_{I C T}\left(\Delta \ln K_{I C T}-\Delta \ln H\right)+v_{O}\left(\Delta \ln K_{O}-\Delta \ln H\right)+v_{L}(\Delta \ln L-\Delta \ln H)+\Delta \ln A
\end{aligned}
$$

There are four sources of labour productivity growth. The first one is ICT capital deepening, i.e. the share weighted increase of ICT capital services per hour worked. The second source is the share weighted deepening of other capital. The third component is the improvement in labour quality which is defined as the difference between the growth rates of labour services and hours worked multiplied by labour's income share. The fourth source is a general advance in multi-factor productivity which increases labour productivity point for point.

Jorgenson and Griliches (1967) showed that it is important to account for substitution between capital and labour of different quality. Similarly as the services provided by a truck built in 1968 and a truck from the year 1998 differ, also the hours worked by a high school dropout and by a holder of a Master's degree are not equal. The aggregate capital service flow, which is assumed to be proportional to the capital stock, is estimated by using asset-specific user costs to weight each heterogeneous asset and to account for substitution between them. Under competitive markets and 
equilibrium conditions, user costs reflect the marginal productivity of the different assets. They thus provide a means to incorporate differences in the productive contribution of heterogeneous investments as the composition of investments and capital changes. For example, as firms respond to fast declining ICT prices by substituting away from other capital equipment or structures and toward ICT equipment, a larger portion of investment will be in assets with relatively high marginal products, and the aggregate capital service flow increases. This can also be interpreted as an increase in the quality of capital.

The user cost of ICT capital services is also needed in estimating the share of nominal income accruing to ICT capital. It is obtained as

$$
r_{I C T}=p_{I C T}\left(i+d_{I C T}-\Delta \ln p_{I C T}\right) \text {, }
$$

where $p_{I C T}$ is the asset price of new ICT capital goods and $\Delta \ln p_{I C T}$ its rate of change, $i$ is the internal rate of return and $d_{I C T}$ denotes depreciation. ICT capital's income share is then obtained as $r_{I C T} \bar{S}_{I C T} / p_{Y} Y$ where $\bar{S}_{I C T}$ is the mid-year real stock of ICT capital and $p_{Y}$ is the output price. The productive capital stock at yearend $t$ for a homogeneous capital asset type is defined as the following perpetual inventory equation:

$$
S(t)=S(t-1)(1-d)+I_{t}=\sum_{\tau=0}^{\infty}(1-d)^{\tau} I(t-\tau),
$$

where $I$ is investment. The symbol for asset type has been left out for notational simplicity.

For labour the difference between labour quantity and labour services (hours worked adjusted for labour quality) is distinguished. The hours worked are cross-classified by educational level and by age. The average wages and salaries of each group are assumed to represent their marginal productivity. Labour quality is defined as the ratio of labour services to hours worked. The variable $\Delta \ln L-\Delta \ln H$ measures its rate of change in equation (4). Labour quality increases as firms hire relatively more skilled and highly compensated workers.

\section{The data}

Our basic computational framework is the balance of aggregate supply and demand. Gross domestic product (GDP) at market prices plus imports equals private and government consumption expenditure plus investment plus changes in inventories plus exports:

$$
\mathrm{GDP}+\text { Imports }=\text { Consumption }+ \text { Investment }+\Delta \text { Inventories }+ \text { Exports. }
$$

When imports are moved to the right-hand side of the identity GDP is calculated using the expenditure approach.

The official investment asset breakdown is further refined here by separating from 
other machinery and equipment the following capital goods: $\mathrm{CPA}^{3} 30.01$ Office machinery, CPA 30.02 Computers, CPA 31.3 Insulated wire and cable, CPA 32.1 Electronic components, CPA $32.2 \mathrm{TV}$ and radio transmitters and CPA $32.3 \mathrm{TV}$ and radio receivers. This plus software (less office machinery) is what we define as ICT capital.

To obtain data on nominal ICT investment, we turned to the detailed annual supply and use tables of Statistics Finland for the years 1995-2002. Of the grand total of 952 goods and services we delineated those pertaining to ICT (see the Appendix for the main groups). To compute ICT investment in current prices for 1975-94 we used a modified version of the commodity-flow method of Timmer, Ypma and van Ark (2003). ${ }^{4}$ The idea is to compile annual series of domestic production, exports and imports and to multiply their sum with a ratio of ICT investment to production plus imports less exports from a benchmark input-output table:

$$
I_{I C T}(t)=\left(Q_{I C T}(t)+M_{I C T}(t)-E_{I C T}(t)\right)\left(\frac{I_{I C T}^{U}}{Q_{I C T}^{I O}+M_{I C T}^{I O}-E_{I C T}^{I O}}\right),
$$

where $I_{I C T}$ is investment in an ICT good, $Q_{I C T}$ is domestic production, $M_{I C T}$ is imports and $E_{I C T}$ is exports. The superscript $U$ denotes the use table of 1995 and the superscript $I O$ the input-output table of 1995.

Traditionally price indexes are compiled by comparing the same product's prices in adjacent periods. In the case of ICT's rapid technological advances, the situation is more complex. Products appear and disappear at a rapid pace. That is why so called hedonic indexes should be used instead of the traditional matched-model indexes. Hedonic functions are relations between the prices of characteristics, such as computer speed, to the prices of the goods themselves. Unfortunately hedonic indexes do not exist for Finnish ICT products, which is why we turned to data from the US Bureau of Economic Analysis (BEA). The methodology utilized is broadly that of Schreyer (2000). The annual changes in the BEA's price index for private non-ICT fixed investments were contrasted with the annual changes in the BEA's price indexes for office equipment, computers, software and communication equipment, respectively. The four series thus obtained were first smoothed using the Hodrick-Prescott (1997) filter, after which they were multiplied with the implicit Finnish aggregate investment deflator to obtain the Finnish quality adjusted ICT deflators. In addition to investments, the ICT deflators were also applied to imports and exports of information and communications products. The result is that our GDP measure somewhat differs from the official one. ${ }^{5}$

\footnotetext{
${ }^{3}$ CPA is Statistical Classification of Products by Activity in the European Economic Community, 2002 version, see:

http://europa.eu.int/comm/eurostat/ramon/nomenclatures/index.cfm?TargetUrl=LST_NOM_DTL\&Str Nom $=$ CPA\&StrLanguageCode $=$ EN\&IntPcKey $=$

${ }^{4}$ For software an official time series existed.

${ }^{5}$ The quality adjusted average GDP growth for 1995-2002 is 4.09 per cent, as we will see in the next section. Since the official estimate is 3.9 per cent, we conclude that the impact of quality adjustment is minor. This is interesting from a policy perspective. The recent step-up in US growth has been traced to ICT. Since European studies are lacking similar evidence it has been suggested that the increase in
} 
Productive capital stocks for each homogeneous asset type were calculated with the perpetual inventory method utilizing geometric depreciation rates. The depreciation rates used were: 0.012 for dwellings, 0.025 for non-residential buildings and civil engineering constructions, 0.25 for transportation equipment, 0.13 for non-ICT equipment, 0.33 for mineral exploration and originals, 0.012 for transfer of ownership of land, 0.315 for office machinery and computers, 0.11 for all communication equipment, and 0.315 for software. No rate of depreciation was applied to cultivated assets. ${ }^{6}$ The user costs were used as weights to aggregate the stocks into a measure of capital services. For the internal rate of return $i$ contained in the user cost formula (5), we used the realized rate of return derived from national accounts.

The labour input and its remuneration were divided into 36 classes. Labour was cross-classified by three age groups (15-24 years, 25-54 years and 55-74 years), six educational classes (lower secondary education or less, upper secondary education, first stage of tertiary education (i-iii) and second stage of tertiary education) as well as by occupational status (employee or self-employed). The labour compensations were used as weights in aggregating the labour hours per class into a measure of labour services.

\section{The results}

The upper panel of Table 1 shows the impact of the production of ICT goods and services as well as other products on the Finnish economy in the years 1995-2002. The first column contains the nominal output shares and the second column the volume growth of production. In the third column are the contributions ${ }^{7}$ to GDP growth. We can see that ICT production's GDP share is 6 per cent - the largest among OECD countries (OECD, 2004) - and its volume growth 23 per cent. ${ }^{8}$ The growth contribution is 1.27 percentage points. Approximately one-third (31\%) of the 4.09 per cent GDP growth stemmed from ICT production, which encompasses the production of computers, software, communications equipment and telecommunications services (see the Appendix).

The panel in the middle of Table 1 reports the results of growth accounting on the input side. On average, ICT-capital contributed 0.66 percentage points to GDP growth. This means that 16 per cent of growth was due to ICT investments. The

US growth is a statistical artifact due to the hedonic quality adjustment. Clearly, this is not the case for Finland.

${ }^{6}$ Cultivated assets encompass only livestock for breeding and dairy in Finland. The European practice is to include a so called culling discount -the difference between the value of a production animal less its slaughter value - on this investment item as a proxy for depreciation. Hence using the PIM on cultivated assets is out of the question.

7 The Törnqvist index is used throughout the paper in aggregations and computations of growth contributions. The volume growth is thus weighted with the average $t$ and $t-1$ nominal shares. The implication of using the Törnqvist index for GDP calculations with the expenditure approach is that the term for changes in inventories (which occasionally is negative) had to be distributed to the other expenditure items. This was done in relation to each other expenditure item's relative size.

${ }^{8}$ ICT production is deflated with our quality adjusted deflators. 
contribution of total capital services was 1.03 percentage points. Information and communications technology alone thus stood for more than half the contribution although its share of the nominal mid-year capital stock in 2002 was still less than 4 per cent. The big contribution is explained by the rapid growth of ICT capital services at the average rate of 17.49 per cent.

Table 1 Average growth of GDP and its components, 1995-2002

\begin{tabular}{lccc}
\hline & $\begin{array}{c}\text { Share of } \\
\text { GDP }^{*}\end{array}$ & $\begin{array}{c}\text { Volume } \\
\text { growth }^{* *}\end{array}$ & Contribution $^{* *}$ \\
\hline GDP at market prices & 100.00 & 4.09 & 4.09 \\
Production of goods and services & & & \\
$\quad$ ICT products & 5.96 & 22.83 & 1.27 \\
$\quad$ Other products & 94.04 & 3.00 & 2.82 \\
Capital services & 33.24 & 3.05 & 1.03 \\
$\quad$ Dwellings & 8.30 & 2.21 & 0.20 \\
ICT capital & 3.60 & 17.49 & 0.66 \\
Other capital & 21.34 & 0.90 & 0.19 \\
Labour services & 66.76 & 1.85 & 1.24 \\
Multi-factor productivity & & & 1.81 \\
Capital quality & 33.24 & 0.83 & 0.28 \\
Capital quantity & 33.24 & 2.22 & 0.75 \\
Labour quality & 66.76 & 0.27 & 0.18 \\
Labour quantity & 66.76 & 1.58 & 1.06 \\
\hline
\end{tabular}

Notes: * per cent, ${ }^{* *}$ In per cent

Numbers may not add to totals due to rounding.

Our estimate for the growth contribution of ICT-capital is quite close to other estimates. Using unofficial ICT-data we estimated the contribution to be 0.6 percentage points in the years 1995-2001 in the non-residential market sector (Jalava \& Pohjola, 2002; Jalava, 2003). In their comparison of EU countries, Timmer, Ypma and van Ark (2003) ended up at 0.7 percentage points for Finland in the same period.

In the light of these results, the growth contribution of ICT seems to be considerably smaller in Finland than in the US, but somewhat larger than in the UK. Calculations using similar methodologies found the contribution to have been 0.93 percentage points in the US in 1995-2001 and 0.57 percentage points in the UK in 1994-98 (Jorgenson, Ho and Stiroh, 2003; Oulton, 2002).

Capital quality rises when capital services grow faster than capital quantity. As reported in the lower panel of Table 1, capital quantity grew on average by 0.83 per cent in 1995-2002. As capital's income share was one third, the contribution of quality was 0.28 percentage points. Consequently, capital quality contributed about one-quarter and capital quantity three-quarters of the total contribution of capital services at the rate of 1.03 percentage points. 
As can be further seen from Table 1, 1.24 percentage points of GDP growth can be attributed to labour services. Labour quality contributed 0.18 and quantity 1.06 percentage points.

The combined growth effect of the inputs was 2.27 percentage points which is somewhat more than half (55.5 per cent) of GDP growth. The residual or multi-factor productivity term, i.e., our estimate for technological change broadly defined, contributed the remaining 1.81 percentage points.

Table 2 shows the decomposition of labour productivity growth. As already seen in Table 1, GDP grew at the pace of 4.09 per cent and the hours worked at the rate of 1.58 per cent. Hence, labour productivity increased on average by 2.51 per cent a year. The contribution of ICT capital deepening was 0.60 whereas dwellings and other capital contributed 0.06 and -0.15 percentage points, respectively.

The culprit behind the recent shift to slower gear in labour productivity growth is the negative contribution of other capital deepening. The volume of other capital per hour worked decreased by 0.67 per cent annually, whereas the volume of ICT capital deepening increased by nearly 16 per cent each year. The contribution of labour quality was 0.18 percentage points and that of MFP 1.81 percentage points.

Table 2 Average growth of labour productivity and its components, 1995-2002

\begin{tabular}{lccc}
\hline & $\begin{array}{c}\text { Share of } \\
\text { GDP }^{*}\end{array}$ & $\begin{array}{c}\text { Volume } \\
\text { growth }^{* *}\end{array}$ & Contribution $^{* *}$ \\
\hline GDP at market prices & 100.00 & 4.09 & 4.09 \\
Hours worked & & 1.58 & 1.58 \\
Labour productivity & 33.24 & 2.51 & 2.51 \\
Capital deepening & 8.30 & 1.47 & 0.51 \\
Dwellings & 3.60 & 15.90 & 0.06 \\
ICT capital & 21.34 & -0.67 & 0.60 \\
Other capital & 66.76 & 0.27 & -0.15 \\
Labour quality & & 1.81 & 1.81 \\
Multi-factor productivity & & & 0.48 \\
ICT related contribution & & & 1.33 \\
Other contribution & & & \\
\hline Notes: ${ }^{*}$ per cent, ${ }^{* *}$ In per cent & &
\end{tabular}

Although the contribution of ICT capital deepening is the strongest among the components of capital services, it is smaller than in the US and close to that in the UK. The contribution was 0.85 percentage points in the US in 1995-2001 and 0.64 percentage points in the UK in 1994-98 (Jorgenson, Ho and Stiroh, 2003; Oulton, 2002).

In the last two rows of Table 2, the aggregate multi-factor productivity growth is decomposed into ICT related and other contributions in the way specified in equation (3). Of the total increase at the rate of 1.81 per cent, 0.48 percentage points came 
from ICT production and 1.33 percentage points from other production. Hence, about one--quarter of the aggregate MFP growth can be attributed to this new technology. The respective contribution was 0.41 percentage points in the US in 1995-2001 (Jorgenson, Ho and Stiroh, 2003).

ICT's overall contribution to labour productivity growth is obtained by summing up the impacts of ICT capital deepening (0.60) and ICT-related multi-factor productivity growth (0.48). The result is 1.08 percentage points, i.e. 43 per cent of the observed growth of GDP per hour worked at the rate of 2.51 per cent. Consequently, without the impacts from information and communications technology, the rate of labour productivity growth would have dropped to below 1.5 per cent.

\section{Conclusions and projections for the future}

In this paper, we took stock of the impacts of information and communications technology on output and labour productivity growth in Finland over 1995-2002. We found that nearly one-third of the quality adjusted GDP growth at the rate of 4.09 per cent stemmed from ICT production. This is remarkable as the nominal share of ICT production was only 6 per cent.

On the input side, our growth accounting results showed that ICT capital services contributed 0.66 percentage points to economic growth. The contribution of total capital services was 1.03 percentage points, so information and communications technology alone stood for more than one-half of the contribution.

Multi-factor productivity increased at the annual rate of 1.81 per. ICT production accounted for 0.48 percentage points. Adding this to the contribution from ICT capital services, we find that ICT's overall impact on GDP growth was 1.14 percentage points. This is 28 per cent of the observed growth rate.

Labour productivity increased on average by 2.51 per cent a year. The contribution of ICT capital deepening was 0.60. Summing this up with the ICT-related multifactor productivity growth, we obtained the conclusion that ICT accounted altogether for 1.08 percentage points of the improvement in GDP per hour worked. This amounts to 43 per cent of the observed labour productivity growth.

We found the culprit behind the recent shift to a slower gear in labour productivity growth to be the negative contribution of other than ICT capital deepening. Without the beneficial effect of ICT, the slowing down of productivity growth would have been even more dramatic.

But what are the future prospects of the Finnish economy? We can make a simple projection on the basis of the growth accounting analysis of labour productivity. Assuming that the economy will be in a steady-state where output and capital services grow at the same rate, we obtain from equation (4) that

(9) $\Delta \ln Y-\Delta \ln H=\Delta \ln L-\Delta \ln H+\Delta \ln A / v_{L}$.

We have estimated elsewhere that the growth of labour quality $\Delta \ln L-\Delta \ln H$ is likely 
to turn negative and may lie in the range between -0.10 and $-0,15$ per cent in the coming years (Jalava and Pohjola 2004). This follows from the adverse effects of aging population on labour productivity. Assuming that labour's income share and multi-factor productivity growth will be the same in the future as in 1995-2002, equation (9) predicts that labour productivity will grow at a rate between 2.5 and 2.6 per cent.

This projection may be on the optimistic side because multi-factor productivity growth might have been exceptionally high in the period considered as the economy was recovering from the deep recession in the early 1990s. But even if MFP growth were to decline to more modest numbers, the growth prospects of the Finnish economy are not as gloomy as often claimed in the public debate.

\section{References}

Hodrick, R.J. and Prescott, E.C. (1997), Postwar U.S. business cycles: An empirical investigation, Journal of Money, Credit and Banking, 29 (1), 1-16.

Jalava, J. (2003), The new economy in Finland: Production and use of ICT (in Swedish), Ekonomiska Samfundets Tidskrift, 56 (1), 17-24.

Jalava, J. and Pohjola, M. (2002), Economic growth in the new economy: Evidence from advanced economies, Information Economics and Policy, 14 (2), 189-210.

Jalava, J. and Pohjola, M. (2004), Finnish labour productivity in 1900-2003 and growth projections for the years 2004-2030 (in Finnish), Finnish Economic Journal, 100 (4), 355-370.

Jorgenson, D.W., Ho, M.S. and Stiroh, K.J. (2003), Lessons from the U.S. growth resurgence, Journal of Policy Modeling, 25 (5), 453-470.

Jorgenson, D.W. and Griliches, Z. (1967), The explanation of productivity change, Review of Economic Studies, 34 (3), 249-283.

OECD (2004), Information technology outlook 2004. Paris: OECD.

Oulton, N. (2002), ICT and productivity growth in the United Kingdom, Oxford Review of Economic Policy, 18 (3), 363-379.

Schreyer, P. (2000), The contribution of information and communication technology to output growth: A study of the G7 countries, OECD STI Working Paper 2000/2.

Timmer, M., Ypma, G. and van Ark, B. (2003), IT in the European Union: Driving productivity divergence? Groningen Growth and Development Centre Research Memorandum GD-67. 


\section{Appendix}

Production of ICT goods and services:

30.02 Computers and other information processing equipment

31.3 Insulated wire and cable

32.1 Electronic valves and tubes and other electronic components

32.2 Television and radio transmitters; apparatus for line telephony and telegraphy

32.3 Television and radio receivers; sound or video recording or reproducing apparatus and associated goods

64.2 Telecommunications services

72 Computer and related services

ICT capital:

30.02 Computers and other information processing equipment

31.3 Insulated wire and cable

32.1 Electronic valves and tubes and other electronic components

32.2 Television and radio transmitters; apparatus for line telephony and telegraphy

32.3 Television and radio receivers; sound or video recording or reproducing apparatus and associated goods

Software 